\title{
Geographical patterns of chromosomal differentiation in the brachypterous grasshopper Podisma sapporensis (Orthoptera: Acrididae)
}

\author{
ElżBIETA WARCHAŁOWSKA-ŚLIWA ${ }^{1}$, HARUKI TATSUTA ${ }^{2}$, SHIN-ICHI AKIMOTO ${ }^{3}$, ANNA \\ MARYAŃSKA-NADACHOWSKA ${ }^{1}$, MAREK KOWALCZYK $^{1}$ and ALEXANDER BUGROV ${ }^{4}$
}

\author{
${ }^{1}$ Department of Experimental Zoology, Institute of Systematics and Evolution of Animals, Polish Academy of Sciences, \\ Sławkowska 17, 31-016 Kraków, Poland; e-mail: warchalowska@isez.pan.krakow.pl \\ ${ }^{2}$ Laboratory of Ecological Risk Assessment, Research Centre for Environmental Risk, National Institute for Environmental Studies, \\ 16-2, Onogawa, Tsukuba, Ibaraki 305-8506, Japan \\ ${ }^{3}$ Systematic Entomology, Department of Ecology and Systematics, Graduate School of Agriculture, Hokkaido University, Sapporo, \\ 060-8589, Japan \\ ${ }^{4}$ Novosibirsk State University, 630090 Novosibirsk and Institute of Systematics and Ecology of Animals, Siberian Branch of \\ Russian Academy of Sciences, 630091 Novosibirsk, Russia
}

Key words. Grasshoppers, Acrididae, Podisma, chromosomes, evolution, polymorphism, chromosome races

\begin{abstract}
The distribution patterns of the X0/XX and neo-XY/neo-XX chromosome races, subraces, and "hybrids" between subraces of the grasshopper $P$. sapporensis were analyzed. The origin of the observed variation is Robertsonian translocations between a sex chromosome and an autosome, and chromosome rearrangements. The fixation levels of inversions varied depending on geographic regions. No hybrid population is known implying that a strong reproductive isolation system exists in hybrids between the different chromosomal races. The probable reasons for the purity of $\mathrm{X} 0$ and neo-XY chromosome races and high chromosome polymorphism in contact zones between chromosomal subraces are discussed. The presence of isolating barriers between chromosome races indicates a review of the taxonomic structure of $P$. sapporensis is required. It is proposed to divide $P$. sapporensis into two sibling species, which differ in the chromosome mechanisms of the sex determination system. The analysis of the distribution of chromosomal races and subraces of $P$. sapporensis allows a reconstruction of the history of this species in the Okhotsk sea region.
\end{abstract}

\section{INTRODUCTION}

Chromosome rearrangements and their role in speciation are well known phenomena in various organisms, but only a few grasshopper species show complex chromosomal polymorphism across their geographical distributions (White, 1973, 1974; Shaw \& Wilkinson, 1980; Shaw et al., 1976; Moran \& Shaw, 1977; Coates \& Shaw, 1982; Hewitt, 1979; John, 1983; Gosalvez et al., 1997).

Two species of brachypterous grasshoppers belonging to the genus Podisma Berthold, namely $P$. pedestris and $P$. sapporensis, show chromosome polymorphism. $P$. pedestris is widely distributed in the Palearctic region from Western Europe to Eastern Siberia (Mistschenko, 1952). This species consists of two distinct chromosomal races. In a large part of its distribution, in Europe and Asia, $P$. pedestris has the $\mathrm{X} 0 / \mathrm{XX}$ sex chromosome determination system with a diploid chromosome number of 23 in the male and 24 in the female, similar to many other grasshoppers (White, 1973; Hewitt, 1979; John, 1983) and therefore considered to be an ancestral type. However, several local populations of this species in the Southern French Alps have the neo-XY/neo-XX system derived from a Robertsonian translocation of the $\mathrm{X}$ chromosome to an autosome with a diploid number of 22 in each sex (John \& Hewitt, 1970; Hewitt \& John, 1972; Barton \& Hewitt, 1985).
Three species belonging to the genus Podisma are distributed on the islands of Okhotsk and in the Japan Sea region. P. sapporensis Shir. occurs on Hokkaido, Sakhalin and Kunashiri Islands (Shiraki, 1910; Bey-Bienko, 1949; Storozhenko, 1993), P. tyatiensis Bugrov et Sergeev is endemic to Tyatya volcano (northern part of Kunashiri Island) (Bugrov \& Sergeev, 1997), whereas $P$. kanoi Storozhenko occurs in the central part of Honshu (Storozhenko, 1993). P. sapporensis is conspicuously different, especially in its morphology (Tatsuta et al., 2000) and cytological features (Bugrov, 1995; Bugrov et al., 2000, 2001, 2003; Warchałowska-Śliwa et al., 2001). This species consists of many geographic races (Akimoto et al., 1993; Tatsuta \& Akimoto, 1994, 1998; Tatsuta et al., 2000) and their taxonomic status is still a matter of controversy (Bey-Bienko, 1949; Storozhenko, 1993; Bugrov \& Sergeev, 1997; Tchernykh \& Bugrov, 1997; Tatsuta et al., 2000). This polytypic species consists of four subspecies, and two of them, P. sapporensis sapporensis (Shir.) and P. s. ashibetsuensis Storozhenko, occur on Hokkaido (Storozhenko, 1993). The distribution of $P$. sapporensis krylonensis Storozhenko is restricted to the Krylion peninsula of Sakhalin, and P. sapporensis kurilenensis (Bey-Bienko) inhabits the central and southern parts of Kunashiri (Storozhenko, 1993).

In previous work, two chromosome races of $P$. sapporensis were detected (Bugrov et al., 2000, 2001). The 


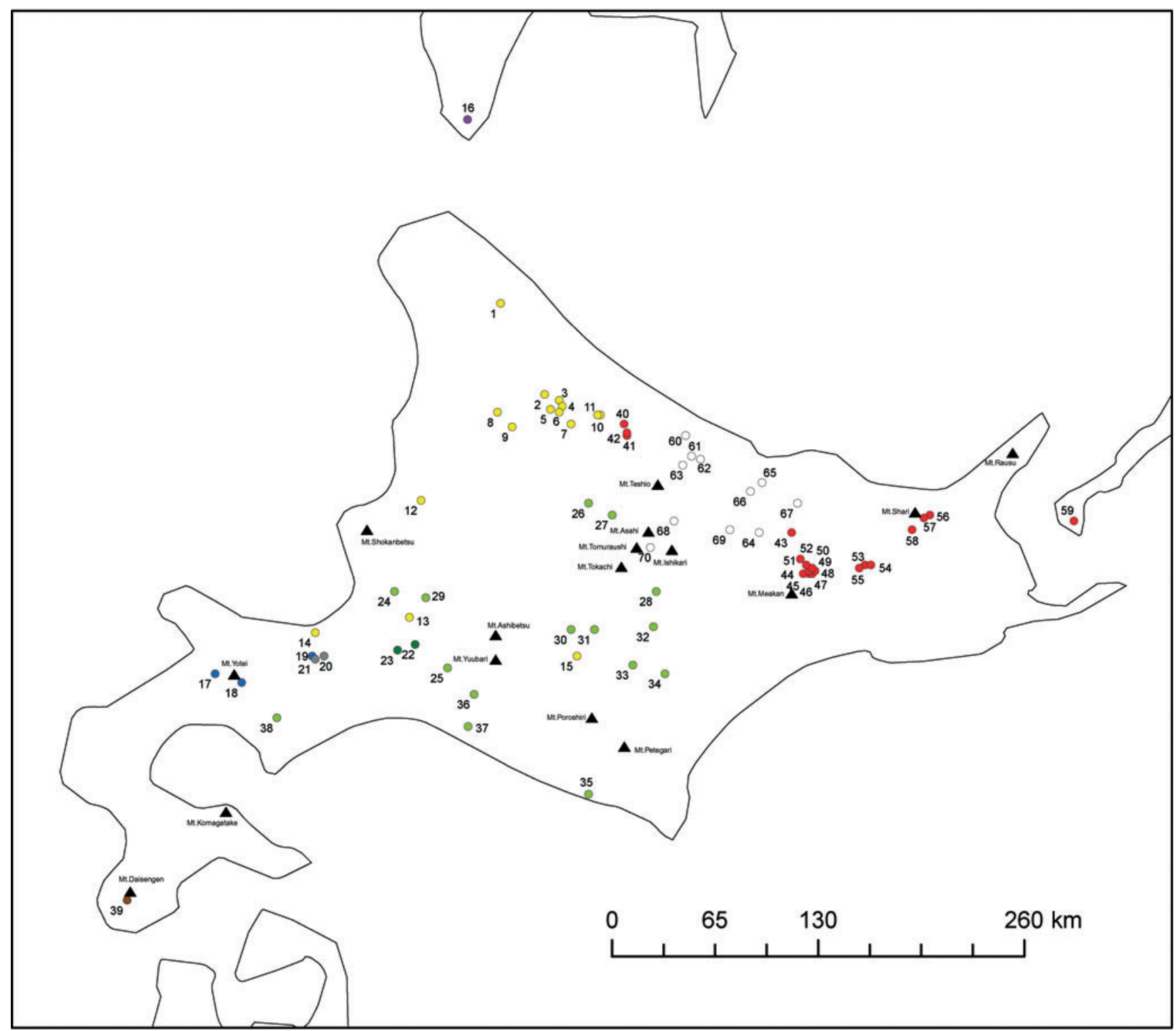

Fig. 1. Distribution of the localities where Podisma sapporensis was sampled. Numbers are the same as in Table 1. Races/subraces are indicated by different colours (yellow - X0/XX-Standard; violet - X0/XX-Sakhalin; blue - X0/XX-Yotei; grey - X0/XXStandard $\times$ Yotei; dark-green $-\mathrm{X} 0 / \mathrm{XX}$-Naganuma; light-green $-\mathrm{X} 0 / \mathrm{XX}$-Naganuma $\times$ Yotei; brown $-\mathrm{X} 0 / \mathrm{XX}$-Daisengen; red $\mathrm{XY} / \mathrm{XX}$-Standard; white $-\mathrm{XY} / \mathrm{XX}$-Tanno/Oketo).

western group of populations on Hokkaido and the population on Sakhalin (Krylion peninsula) have the X0/XX sex chromosome determination. The eastern group of populations on Hokkaido and the population on Kunashiri Is. (Golovnin volkano) belong to the neo-XY/XX race, which differs from the $\mathrm{X} 0$ race by a Robertsonian translocation between the originally acrocentric $\mathrm{X}$ chromosome and $\mathrm{M}_{5}$ autosome in a homozygous state (sex determination is neo-XY male/neo-XX female, $2 \mathrm{n}=22$ ). Moreover, in several populations, the pericentric inversion is fixed in one or more pairs of chromosomes, a key character distinguishing discrete karyomorphs (chromosome subraces). Interestingly, various levels of polymorphism in both chromosome races result from pericentric inversions, $\mathrm{C}$-banding variation and the occurrence of additional (B) chromosomes (Bugrov et al., 2001, 2003; WarchałowskaŚliwa et al., 2001). The level of diversity in the P. sap- porensis karyotypes is substantially higher than in other species of Podismini grasshoppers distributed in the Palearctic region, suggesting a unique model of cytogenetic evolution in Orthoptera. In this paper, the pattern of chromosome divergence across the range of $P$. sapporensis is reviewed. We aimed to summarize the distribution patterns of each chromosomal race and subrace, and determine the border-zones of distribution of the chromosome races and subraces. The results were used to consider the number of potential areas of contact between different chromosomal races and the phylogeographical scenario for explaining chromosomal diversification in $P$. sapporensis.

\section{MATERIAL AND METHODS}

During July/August in the year 1999-2005, a total of 1500 males and 250 females of $P$. sapporensis sapporensis were col- 
TABLE 1. Summary of the locations, year of collection, samples size, and chromosome race/subrace type of Podisma sapporensis. Locality number (No.) refers to Table 1 and Fig. 1; e-embryos.

\begin{tabular}{|c|c|c|c|c|c|c|c|c|c|c|c|c|}
\hline No. & Locality name & Latitude & Longitude & 1999 & 2000 & 2001 & 2002 & 2003 & 2004 & 2005 & Total & Chromosome type \\
\hline 1 & Nakatombetsu & 44.967 & 142.267 & & 7 & & & & & & 8 & X0/XX-Standard \\
\hline 2 & Bifuka & 44.45 & 142.517 & 6 & & & & & & & 6 & X0/XX-Standard \\
\hline 3 & Shimokawa-D & 44.417 & 142.6 & 1 & $7 \mathrm{e}$ & & & & & & 8 & $\mathrm{X} 0 / \mathrm{XX}-\mathrm{Standard}$ \\
\hline 4 & Shimokawa-B & 44.383 & 142.617 & 10 & & & & & & & 10 & X0/XX-Standard \\
\hline 5 & Shimokawa-C & 44.3667 & 142.55 & 5 & & & & & & & 5 & $\mathrm{X} 0 / \mathrm{XX}-\mathrm{Standard}$ \\
\hline 6 & Shimokawa-A & 44.35 & 142.6 & 11 & & & & & & & 11 & $\mathrm{X} 0 / \mathrm{XX}-\mathrm{Standard}$ \\
\hline 7 & Shimokawa (2005) & 44.283 & 142.667 & & & & & & & 68 & 68 & X0/XX-Standard \\
\hline 8 & Moshiri & 44.35 & 142.25 & & & 11 & & & & & 11 & $\mathrm{X} 0 / \mathrm{XX}-\mathrm{Standard}$ \\
\hline 9 & Hinata Spa & 44.267 & 142.333 & & & & & & & 8 & 8 & X0/XX-Standard \\
\hline 10 & Nishi Okoppe-1 & 44.333 & 142.833 & & & & & & & $5,3 \mathrm{e}$ & 8 & X0/XX-Standard \\
\hline 11 & Nishi Okoppe-3 & 44.333 & 142.817 & & & & & & & 3 & 3 & X0/XX-Standard \\
\hline 12 & Togeshita & 43.85 & 141.817 & & & & & & 4 & & 4 & X0/XX-Standard \\
\hline 13 & Bibai & 43.283 & 141.833 & & & & & 14 & & & 14 & $\mathrm{X} 0 / \mathrm{XX}-\mathrm{Standard}$ \\
\hline 14 & Mt Teine & 43.1 & 141.217 & 30 & $10 \mathrm{e}$ & & & & 44 & & 84 & $\mathrm{X} 0 / \mathrm{XX}-\mathrm{Standard}$ \\
\hline 15 & Ishiyama & 42.967 & 141.3 & & & & & & & 28 & 28 & $\mathrm{X} 0 / \mathrm{XX}-\mathrm{Standard}$ \\
\hline 16 & Krylion Penninsula & 46.983 & 142.917 & & & & $37,54 \mathrm{e}$ & & & & 81 & X0/XX-Sakhalin \\
\hline 17 & Iwaonobori & 42.867 & 140.65 & & & & & 19 & & & 19 & X0/XX-Yotei \\
\hline 18 & Mt Yotei & 42.817 & 140.8 & 10 & $20,16 \mathrm{e}$ & & & & & & 46 & X0/XX-Yotei \\
\hline 19 & Hyakumatsuzawa & 42.967 & 141.2 & & & & & & & 20 & 20 & X0/XX-Yotei \\
\hline 20 & Kannonzawa & 42.967 & 141.267 & & & & & & 13 & & 13 & $\mathrm{X} 0 / \mathrm{XX}$-Standard $\times$ Yotei \\
\hline 21 & Toyotaki & 42.95 & 141.217 & & & & & & & 20 & 20 & X0/XX-Standard $\times$ Yotei \\
\hline 22 & Kuriyama & 43.033 & 141,783 & $18,5 \mathrm{e}$ & & & & & & & 23 & X0/XX-Naganuma \\
\hline 23 & Naganuma & 43 & 141.683 & 20 & 6 & 15 & & 10 & & & 51 & X0/XX-Naganuma \\
\hline 24 & Tsukigata & 43.333 & 141.667 & & & 11 & & & & & 11 & $\mathrm{X} 0 / \mathrm{XX}$-Naganuma $\times$ Yotei \\
\hline 25 & Yuubari (Takinoue) & 42.9 & 141.967 & & & 24 & & & & & 24 & $\mathrm{X} 0 / \mathrm{XX}$-Naganuma $\times$ Yotei \\
\hline 26 & Kamikawa-1 & 43.833 & 142.767 & 7 & & & & & & & 7 & $\mathrm{X} 0 / \mathrm{XX}-$ Naganuma $\times$ Yotei \\
\hline 27 & Sounkyo & 43.767 & 142.9 & & & 8 & & & & & 8 & $\mathrm{X} 0 / \mathrm{XX}-$ Naganuma $\times$ Yotei \\
\hline 28 & Kamishihoro & 43.333 & 143.15 & & & & & & 8 & & 8 & X0/XX-Naganuma $\times$ Yotei \\
\hline 29 & Iwamizawa & 43.183 & 141.767 & & & 17 & & & & & 17 & $\mathrm{X} 0 / \mathrm{XX}$-Naganuma $\times$ Yotei \\
\hline 30 & Ochiai & 43.117 & 142.667 & & & 14 & & & & & 14 & X0/XX-Naganuma $\times$ Yotei \\
\hline 31 & Sahoro & 43.117 & 142.8 & & & 3 & & & & & 3 & X0/XX-Naganuma $\times$ Yotei \\
\hline 32 & Shirakaba & 43.133 & 143.133 & & & 3 & & & & & 3 & $\mathrm{X} 0 / \mathrm{XX}$-Naganuma $\times$ Yotei \\
\hline 33 & Memuro & 42.917 & 143.017 & & & & & & 2 & & 2 & $\mathrm{X} 0 / \mathrm{XX}$-Naganuma $\times$ Yotei \\
\hline 34 & Obihiro & 42.867 & 143.2 & & & & & & 5 & & 5 & $\mathrm{X} 0 / \mathrm{XX}$-Naganuma $\times$ Yotei \\
\hline 35 & Urakawa & 42.183 & 142.767 & & & & & & 24 & & 24 & X0/XX-Naganuma $\times$ Yotei \\
\hline 36 & Inasato & 42.75 & 142.117 & & & 16 & & & & & 16 & $\mathrm{X} 0 / \mathrm{XX}$-Naganuma $\times$ Yotei \\
\hline 37 & Biratori & 42.567 & 142.083 & & & & & & 2 & & 2 & $\mathrm{X} 0 / \mathrm{XX}$-Naganuma $\times$ Yotei \\
\hline 38 & Kitayuzawa & 42.617 & 141 & & & & & 11 & & & 11 & $\mathrm{X} 0 / \mathrm{XX}$-Naganuma $\times$ Yotei \\
\hline 39 & Mt Daisengen & 41.583 & 140.15 & 5 & 17 & & & & & & 22 & X0/XX-Daisengen \\
\hline 40 & Nishi Okoppe-2,4 & 44.283 & 142.967 & & & & & & & 22 & 22 & $\mathrm{XY} / \mathrm{XX}-$ Standard \\
\hline 41 & Takinoue & 44.217 & 142.983 & & & & & & & 9 & 9 & $\mathrm{XY} / \mathrm{XX}-$ Standard \\
\hline 42 & Sakkuru-Toge & 44.233 & 142.983 & & & & & & & 2 & 2 & $\mathrm{XY} / \mathrm{XX}$-Standard \\
\hline 43 & Tsubetsu & 43.667 & 143.917 & 4 & & & & & & & 4 & $\mathrm{XY} / \mathrm{XX}$-Standard \\
\hline 44 & Ashoro-A & 43.433 & 144.017 & 2 & & & & & & & 2 & $\mathrm{XY} / \mathrm{XX}$-Standard \\
\hline 45 & Ashoro-B & 43.433 & 143.983 & 11 & & & & & & & 11 & $\mathrm{XY} / \mathrm{XX}$-Standard \\
\hline 46 & Akan-A & 43.433 & 144.033 & 10 & $5,7 \mathrm{e}$ & & & & & & 22 & $\mathrm{XY} / \mathrm{XX}$-Standard \\
\hline 47 & Akan-B & 43.45 & 144.05 & 11 & & & & & & & 11 & $\mathrm{XY} / \mathrm{XX}$-Standard \\
\hline 48 & Senpuku-A & 43.45 & 144.017 & 18 & & & & & & & 18 & $\mathrm{XY} / \mathrm{XX}$-Standard \\
\hline 49 & Senpuku-B & 43.483 & 144 & 17 & & & & & & & 17 & $\mathrm{XY} / \mathrm{XX}-$ Standard \\
\hline 50 & Senpuku-C & 43.467 & 144.033 & 14 & & & & & & & 14 & $\mathrm{XY} / \mathrm{XX}$-Standard \\
\hline 51 & Senpuku-D & 43.517 & 143.967 & 7 & & & & & & & 7 & $\mathrm{XY} / \mathrm{XX}$-Standard \\
\hline 52 & Teshikaga-A & 43.467 & 144.3 & 12 & 22 & & & & & & 34 & $\mathrm{XY} / \mathrm{XX}-$ Standard \\
\hline 53 & Teshikaga-B & 43.483 & 144.333 & 11 & & & & & & & 11 & $\mathrm{XY} / \mathrm{XX}-$ Standard \\
\hline 54 & Teshikaga-C & 43.483 & 144.367 & 3 & & & & & & & 3 & $\mathrm{XY} / \mathrm{XX}$-Standard \\
\hline 55 & Teshikaga-2005 & 43.467 & 144.3 & & & & & & & 9 & 9 & $\mathrm{XY} / \mathrm{XX}$-Standard \\
\hline 56 & Mt. Shari & 43.767 & 144.7 & 24 & & & & & & & 24 & $\mathrm{XY} / \mathrm{XX}$-Standard \\
\hline 57 & Mt Etombi & 43.75 & 144.667 & 4 & & & & & & & 4 & $\mathrm{XY} / \mathrm{XX}-$ Standard \\
\hline 58 & Kiyosato & 43.683 & 144.6 & 10 & & & & & & & 10 & $\mathrm{XY} / \mathrm{XX}$-Standard \\
\hline 59 & Golovnin & 43.733 & 145.517 & & & & 5 & & & 7 & 12 & XY/XX-Standard \\
\hline 60 & Kamirubetsu & 44.217 & 143.317 & & & & & & & $14,5 \mathrm{e}$ & 19 & $\mathrm{XY} / \mathrm{XX}$-Tanno/Oketo \\
\hline 61 & Kami-koonomai & 44.1 & 143.35 & & & & & & & 9 & 9 & $\mathrm{XY} / \mathrm{XX}$-Tanno-Oketo \\
\hline 62 & Hakuryu & 44.083 & 143.4 & & & & & & & 24 & 24 & $\mathrm{XY} / \mathrm{XX}$-Tanno/Oketo \\
\hline 63 & Kimpachi-toge & 44.05 & 143.3 & & & & & & & 3 & 3 & $\mathrm{XY} / \mathrm{XX}$-Tanno-Oketo \\
\hline 64 & Rukushi-Toge & 43.667 & 143.733 & & & & & & & 4 & 4 & $\mathrm{XY} / \mathrm{XX}$-Tanno/Oketo \\
\hline 65 & Kitami & 43.95 & 143.75 & & & & & & & 15 & 15 & $\mathrm{XY} / \mathrm{XX}$-Tanno/Oketo \\
\hline 66 & Rubeshibe & 43.9 & 143.683 & & & & & & & 5 & 5 & $\mathrm{XY} / \mathrm{XX}$-Tanno/Oketo \\
\hline 67 & Tanno & 43.833 & 143.95 & 7 & $8,4 \mathrm{e}$ & & & & & & 19 & $\mathrm{XY} / \mathrm{XX}$-Tanno/Oketo \\
\hline 68 & Maruseppu & 43.733 & 143.25 & & & & & & & 42 & 42 & $\mathrm{XY} / \mathrm{XX}$-Tanno/Oketo \\
\hline 69 & Oketo & 43.683 & 143.567 & 7 & $3 \mathrm{e}$ & & & & & 9 & 19 & $\mathrm{XY} / \mathrm{XX}$-Tanno/Oketo \\
\hline \multirow[t]{2}{*}{70} & Kamikawa-2 & 43.583 & 143.117 & & & & & & 2 & & 2 & XY/XX-Tanno/Oketo \\
\hline & TOTAL & & & & & & & & & & 1133 & \\
\hline
\end{tabular}




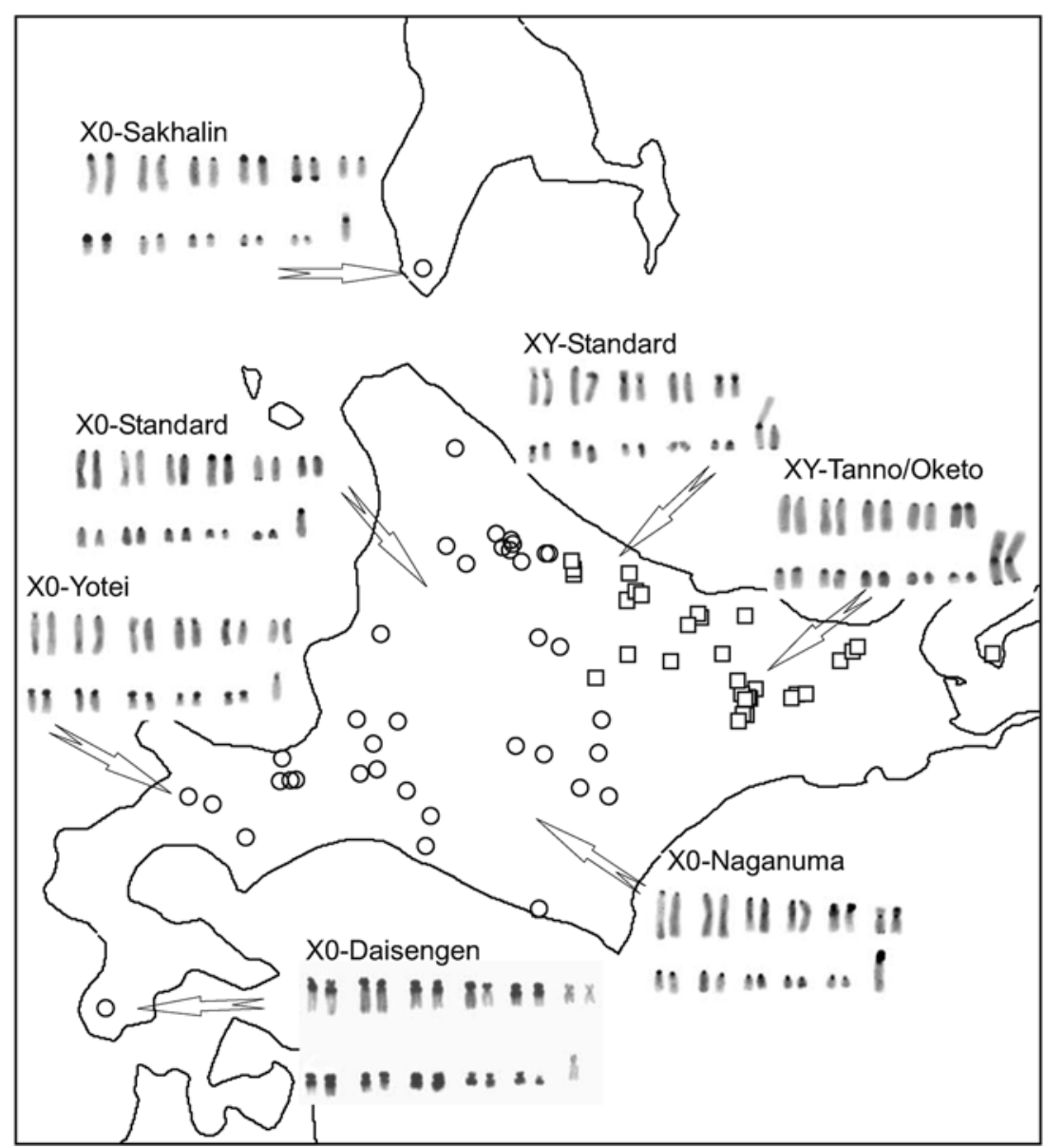

Fig. 2. Distribution of the Podisma sapporensis karyotypes in seven chromosome races/subraces belonging to X0/XX (ring) and neo-XY/XX (square) races.

lected from 68 localities on Hokkaido. In August 2002 and 2004, 37 males and 25 females of $P$. sapporensis krylonensis from Sakhalin Is. (Krylion peninsula), and 12 males of $P$. sapporensis kurilensis from Kunashiri Is. (Golovnin volcano) were collected. The collection sites are named after the closest town/village or geographical region (Fig. 1, Table 1). Twentynine of these localities are already reported in two previous reports (Bugrov et al., 2000, 2001), and the cytogenetic data from these studies are also included in the present study. A total of 1133 males and embryos were studied cytologically and included in the present study (Table 1). The method of preparing chromosome slides of testes and embryos, and the C-banding methods were as previously reported (Bugrov et al., 2000, 2001).

\section{RESULTS}

The results of the cytogenetic analyses of populations from Hokkaido, Sakhalin and Kunshir are given in Table 1. These results are concordant with previous data on chromosome divergence in $P$. sapporensis and indicate two main chromosomal races. The $\mathrm{X} 0 / \mathrm{XX}$ race occurs in the western region of Hokkaido and southern Sakhalin, whereas the neo-XY/XX occurs in the eastern part of Hokkaido and Kunashiri (Figs 1 and 2). These races have a complex polymorphism in terms of pericentric inversions, C-heterochromatin content, additional (B) chromosomes and C-positive second arms, as well as interchanges between B chromosomes and autosomes.

\section{The X0 chromosome race}

In order to describe the distribution area of the $\mathrm{X} 0$ race, individuals from 39 localities of $P$. sapporensis were analysed (Table 1, Fig. 1). On the basis of chromosome polymorphism, this race was subdivided into seven categories: five subraces and two "hybrid" types.

(1) Samples from 15 localities (Table 1, nos 1-15) had the standard chromosome complement of the genus Podisma, i.e., 22 acrocentric autosomes and the acrocentric $\mathrm{X}$ chromosome in males $(2 \mathrm{n} \hat{\sigma}=23, \mathrm{X} 0)$ and two acrocentric $X$ chromosomes in females $(2 \mathrm{n}+=24, \mathrm{XX})$. This type of chromosome set corresponds to the chromosome complement of $P$. sapporensis from the vicinities of Shimokawa and Sapporo (Mt Teine) (see Fig. 2 in Bugrov et al., 2001, Fig. 3). This chromosome morphotype is denoted as "X0/XX-Standard" subrace of $P$. sapporensis (Table 1). This race is distributed from northern to central Hokkaido (Figs 1 and 2).

(2) P. sapporensis from the Sakhalin (Krylion peninsula) population is described as $P$. sapporensis krylonensis (Storozhenko, 1993) (Table 1, Fig. 1, no. 16). The karyotype of this population has 23 chromosomes in the male and 24 in the female and a X0 $0 / \mathrm{XX}$ o sex determination system. All autosome pairs are acrocentric, whereas the X-chromosome is subacrocentric. The euchromatic nature of the short arm of the $\mathrm{X}$ chromosome 


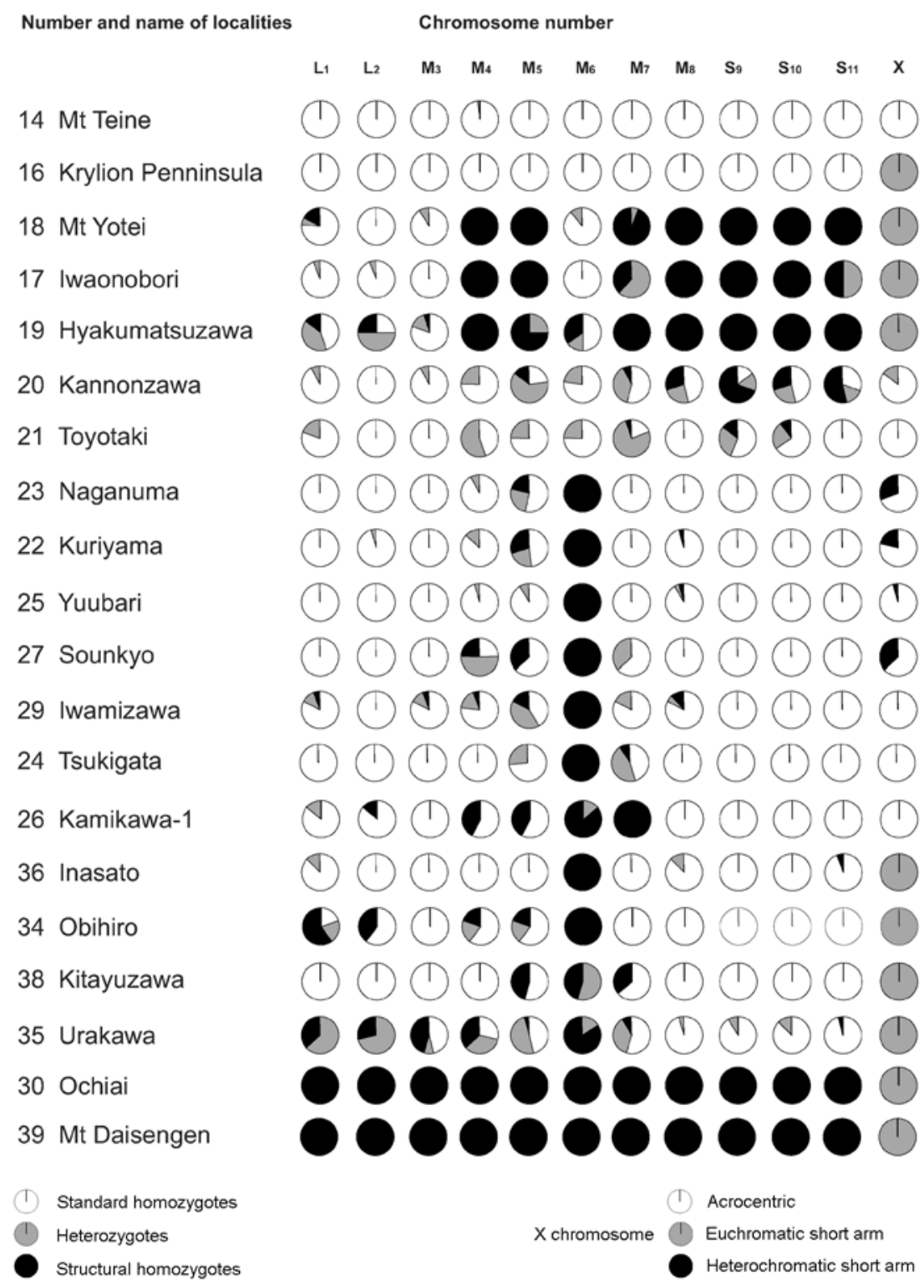

Fig. 3. The frequency distribution of heterozygotes and homozygotes for the pericentric inversion at twenty localities of the $\mathrm{X} 0 / \mathrm{XX}$ race of Podisma sapporensis. Locality number and names of localities correspond to individuals of races/subraces in Table 1 and Fig. 1. Diagrams present results where there are more then 5 individuals.

testifies to its inversion origin. The karyotype of $P$. s. krylonensis is more similar to the standard chromosome complement of the populations at the eleven localities described above, but differs slightly in the fixed pericentric inversion in the X-chromosome (see Fig. 1 in Bugrov, 1995; Fig. 3). This chromosome subrace, "X0/XXSakhalin", is separated by the Laperuz strait from other populations of $P$. sapporensis on Hokkaido and the Okhotsk Sea from the Kunashiri population (Fig. 2).

(3) The "X0/XX-Yotei" subrace differs from other subraces of $P$. sapporensis in having a fixed pericentric inversion resulted in a short euchromatic arm on $\mathrm{M}_{4}$, and the $\mathrm{X}$-chromosome as well as heterochromatic short arms on $\mathrm{M}_{5}$ and $\mathrm{M}_{8}-\mathrm{S}_{10}$ pairs. Additionally, a polymorphism in the short euchromatic short arm on $\mathrm{L}_{1}, \mathrm{~L}_{2}, \mathrm{M}_{3}$, and $\mathrm{M}_{6}$ was revealed (Fig. 3). In contrast, the vast majority of samples possessed short second heterochromatic arms on the $\mathrm{M}_{7}$ and $\mathrm{S}_{11}$ pairs (see Fig. 3 in Bugrov et al., 2001). This subrace occurs at three localities: Mt Yotei, Iwaonobori and Hyakumatsuzawa (Fig. 1, Table 1, nos 17-19). These localities are adjacent to the distribution of the $\mathrm{X} 0 / \mathrm{XX}$-standard subrace and no conspicuous geographic barriers occur between the two subraces, except for Mt Yotei (Fig. 2).

(4) The samples from Naganuma and Kuryama (Figs 1 and 2, Table 1, nos 22 and 23) were homozygous for the pericentric inversion on $\mathrm{M}_{6}$. The inverted segment of $\mathrm{M}_{6}$ forms the euchromatic arm, resulting in the derived morphology of $\mathrm{M}_{6}$ from acrocentric to submetacentric. This pair of autosomes can be used as specific markers. A high frequency of heterozygotes and homozygotes for the inversion on $\mathrm{M}_{5}$, and low frequency of heterozygotes for the inversion on $\mathrm{M}_{4}$, as well as the presence of additional short C-heterochromatic arms on two pairs of autosomes 


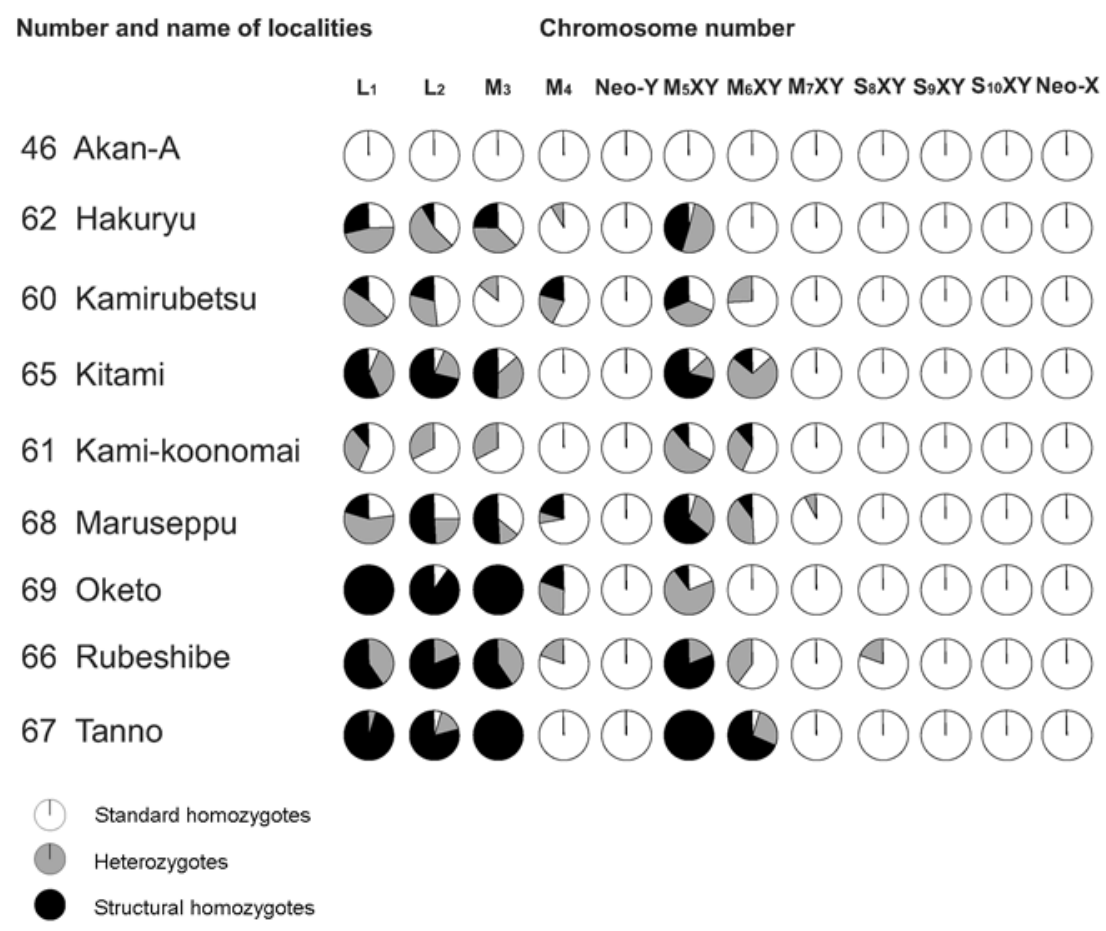

Fig. 4. The frequency distribution of heterozygotes and homozygotes for the pericentric inversion at nine localities of the $\mathrm{XY} / \mathrm{XX}$ race of Podisma sapporensis. Locality number and names of localities correspond to individuals of races/subraces in Table 1 and Fig. 1. Diagrams present results where there are more then 5 individuals.

and the $\mathrm{X}$ chromosome were revealed (see Fig. 6 in Bugrov et al., 2001, Figs 2 and 3). The Ishikari river running through the Naganuma area seems to constitute a barrier between the "X0-Standard" and "X0-Naganuma" subrace.

(5) The population on Mt Daisengen - the "X0/XXDaisengen" subrace (Figs 1 and 2, Table 1, no. 39), differs greatly from other populations belonging to the $\mathrm{X} 0$ chromosome race, not only in the morphology of its chromosomes but also in the localization and amount of C-heterochromatin. All chromosome pairs in representatives of this population had two arms (Fig. 3). Short, second euchromatic arms were observed only on $\mathrm{M}_{6}$ autosomes and X-chromosomes. On the remaining chromosomes the short arms were mostly heterochromatic (see Fig. 4 in Bugrov et al., 2001). The population on Mt Daisengen is completely isolated from other populations and is relatively small. Hence, the inbreeding rate is considered to be extremely high and this novel karyotype may be rapidly fixed due to random genetic drift.

Sixteen out of the 39 localities distributed in the western part and in the centre of the $\mathrm{X} 0 / \mathrm{XX}$ race area were highly polymorphic for short chromosome arms. A substantial amount of chromosome polymorphism associated with pericentric inversions and the additional heterochromatic arm may imply that hybridisation between neighbouring subraces has occurred. According to chromosome markers, the composition of "hybrids" were as follows: 1) between X0/XX-standard and X0/XX-Yotei "X0/XX-standard $\times$ Yotei hybrid" and 2) X0/XXNaganuma and X0/XX-Yotei - "Naganuma $\times$ Yotei hybrid". They are described below.
(6) Thirty-three specimens from two localities (Kannonzawa and Toyotaki) distributed along the border of the X0-Standard and X0 Yotei subraces can be classified as "X0/XX-Standard $\times$ Yotei hybrids" (Fig. 1, Table 1, nos 20 and 21). Most of the autosomes (with the exception of $\mathrm{L}_{2}$ pair) and the $\mathrm{X}$ chromosome are polymorphic, thus the frequency of subacrocentric chromosomes varied among samples as well as chromosome pairs. The vast majority of specimens are heterozygous for chromosome markers characteristic of the "X0 Yotei" subrace (short euchromatic arm on $\mathrm{M}_{6}$, short second heterochromatic arms on $\mathrm{M}_{7}$ and $\mathrm{S}_{11}$ pairs, and morphology of the $\mathrm{X}$ chromosome). On Toyotaki (Fig. 1, no. 21, Fig. 5A, B) an acrocentric $\mathrm{X}$ chromosome was found, which is morphologically similar to $\mathrm{X} 0$-Standard, whereas on Kannonzawa (Fig. 1, Table 1, no. 20; Fig. 5C, D) two of 11 individuals possessed subacrocentric $\mathrm{X}$ chromosomes similar to individuals of X0 Yotei. The diagram shows the frequency of polymorphism in this subrace (Fig. 3). These localities are on the border of X0/XX-standard and $\mathrm{X} 0 / \mathrm{XX}-$ Yotei and there is no geographic barrier in this area.

(7) An analysis of 90 individuals from 13 localities (Fig. 1, Table 1, nos 24-38) revealed high polymorphism for pericentric inversions in each diagnostic chromosome, including the specific markers on chromosome $\mathrm{M}_{6}$ (submetacentric chromosome) and the $\mathrm{X}$ chromosome (acrocentric or subacrocentric with heterochromatic arm) in the "X0 Naganuma" subrace as well as an inversion polymorphism on $\mathrm{L}_{1}-\mathrm{L}_{3}, \mathrm{M}_{6}$ (subacrocentric) and the $\mathrm{X}$ chromosome marker (subacrocentric with short euchromatic second arms) in the X0 Yotei subrace. These individuals 


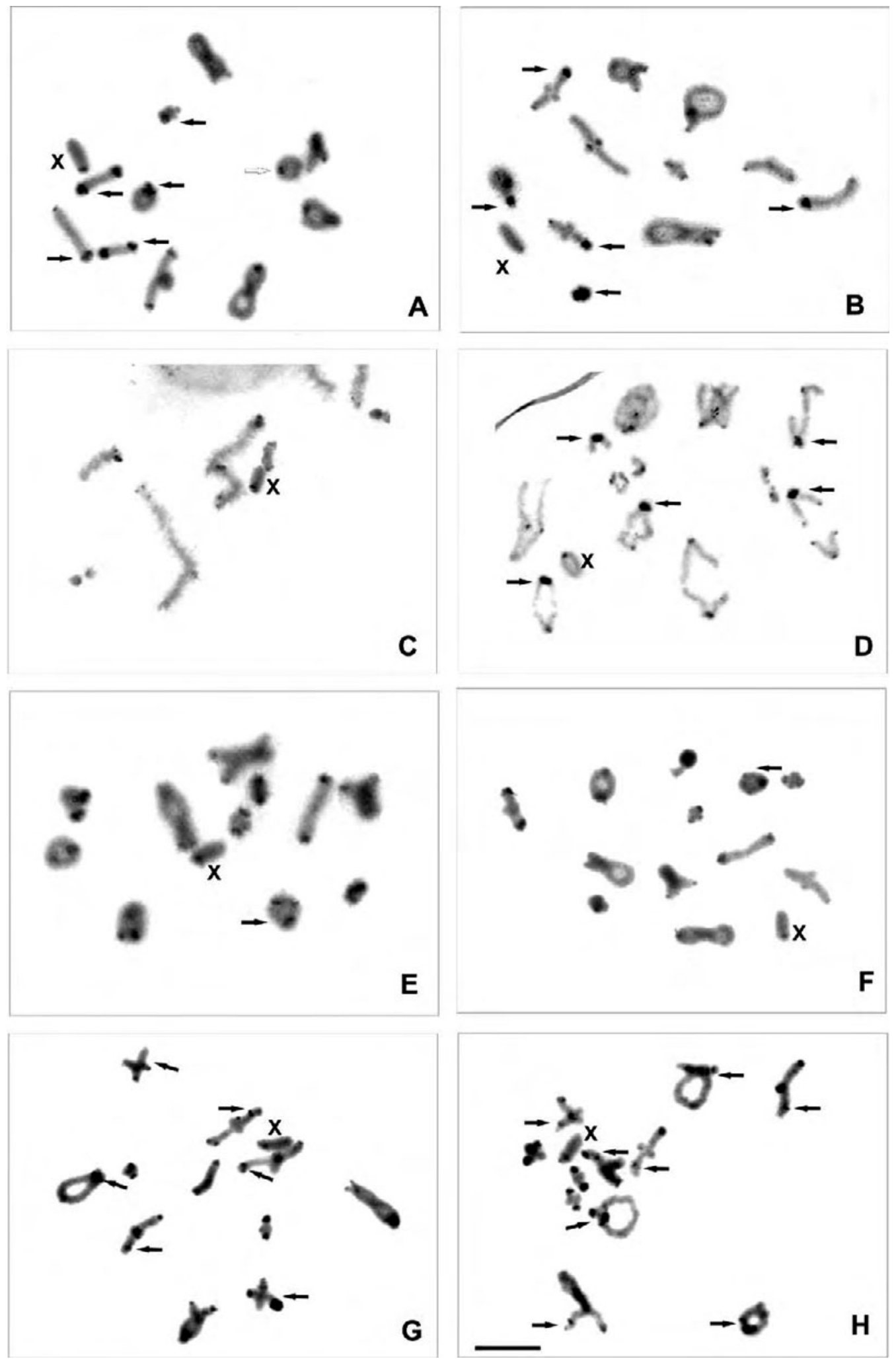

Fig. 5. Meiotic chromosomes of Podisma sapporensis males stained for C-banding. (A-D). X0/XX "Standard $\times$ Yotei hybrids" from Toyotaki (A, B) and Kannonzawa (C, D) localities. (A, B) Diakinesis, heterozygous and homozygous for chromosome markers characteristic of the $\mathrm{X} 0$-Yotei subrace; (A) short heterochromatic arms in heterozygous $\mathrm{M}_{5}, \mathrm{M}_{7}$ and $\mathrm{S}_{11}$ pairs (arrows), homozygous for $S_{9}, S_{10}$, short euchromatic arm on $M_{6}$ (white arrow) and (B) heterozygous for heterochromatic arms on the $M_{5}, M_{6}, M_{7}$ and $S_{9}$ pairs, homozygous for $\mathrm{S}_{11}$, as well as acrocentric for $\mathrm{M}_{4}$. (arrows). The acrocentric X chromosome is morphologically similar to X0Standard. (C) Diakinesis with the X chromosome subacrocentric with euchromatic short arm and (D) anaphase I with acrocentric X chromosome, additionally, $\mathrm{M}_{5}-\mathrm{S}_{9}$ pairs are heterozygous for short arms (arrows). (E-H). X0/XX "Naganuma $\times$ Yotei hybrid" from the Kitayuzawa (E, F) and Urokawa $(\mathrm{G}, \mathrm{H})$ localities. Diakinesis with $(\mathrm{E}, \mathrm{H})$ heterozygous or $(\mathrm{F}, \mathrm{G})$ homozygous for submetacentric $\mathrm{M}_{6}$ chromosome (chromosome markers for X0-Naganuma) (arrows) and the $\mathrm{X}$ chromosome with euchromatin short arm (the marker for X0-Yotei). Additionally, $(G, H)$ homozygous for pericentric inversion on $L_{2}, M_{6}(G)$ and $L_{2}, M_{4}(H)$, as well as heterozygous for pericentric inversion on $\mathrm{M}_{4}, \mathrm{M}_{5}, \mathrm{M}_{7}, \mathrm{M}_{8}(\mathrm{G})$ and $\mathrm{L}_{1} \mathrm{M}_{3}, \mathrm{M}_{4}-\mathrm{M}_{8}(\mathrm{H})$ (arrows). Scale bar $=10 \mu \mathrm{m}$. 
TABle 2. Frequency of the six B chromosomes and translocation between $\mathrm{M}_{3}$ and B in Podisma sapporensis at different localities; unclear type of $\mathrm{B}(\mathrm{Bn})$. Locality number (No.) refers to Table 1 and Fig. 1. BB - standard homozygote; BS - translocation heterozygote; SS - translocation homozygote; e-embryos.

\begin{tabular}{|c|c|c|c|c|c|c|c|c|c|c|c|c|c|c|}
\hline \multirow{2}{*}{ No. } & \multirow{2}{*}{ Locality name } & \multirow{2}{*}{ Chromosome type } & \multirow{2}{*}{ Total } & \multicolumn{8}{|c|}{ B Chromosomes } & \multicolumn{3}{|c|}{ M3 translocation } \\
\hline & & & & 0B & B1 & B2 & B3 & B4 & B5 & B6 & $\mathrm{Bn}$ & $\mathrm{BB}$ & BS & SS \\
\hline 3 & Shimokawa-A & $\mathrm{X} 0 / \mathrm{XX}-\mathrm{Standard}$ & 11 & 9 & & & & & 2 & & & 10 & 1 & \\
\hline 4 & Shimokawa-B & X0/XX-Standard & 10 & 8 & & & 2 & & & & & 9 & 1 & \\
\hline 6 & Shimokawa-D & X0/XX-Standard & 8 & 4 & & & $4 \mathrm{e}$ & & & & & & & \\
\hline 7 & Shimokawa (2005) & X0/XX-Standard & 68 & 56 & & & 2 & & 3 & & 7 & & & \\
\hline 9 & Hinata Spa & X0/XX-Standard & 8 & 5 & & & & & & & 3 & & & \\
\hline 10 & Nishi Okoppe-1 & X0/XX-Standard & 8 & 6 & & & & & 2 & & & & & \\
\hline 12 & Togeshita & $\mathrm{X} 0 / \mathrm{XX}-\mathrm{Standard}$ & 4 & 3 & & & & & & & 1 iso/S9 & & & \\
\hline 14 & Mt Teine & X0/XX-Standard & 84 & 81 & 3 & & & & & & & 81 & 3 & \\
\hline 15 & Ishiyama & X0/XX-Standard & 28 & 20 & & & & & 8 & & & & & \\
\hline 16 & Krylonian Penninsula & X0/XX-Sakhalin & 81 & 65 & $3,13 \mathrm{e}$ & & & & & & & & & \\
\hline 18 & Mt Yotei & X0/XX-Yotei & 46 & 40 & $4,2 \mathrm{e}$ & & & & & & & & & \\
\hline 22 & Kuriyama & $\mathrm{X} 0 / \mathrm{XX}$-Naganuma & 23 & 19 & 1 & 3 & & & & & & 18 & 5 & \\
\hline 23 & Naganuma & X0/XX-Naganuma & 51 & 37 & 10 & 2 & 1 & 1 & & & & 45 & 6 & \\
\hline 25 & Yuubari (Takinoue) & X0/XX-Naganuma $\times$ Yotei & 24 & 20 & & & & 4 & & & & 22 & 2 & \\
\hline 26 & Kamikawa-1 & X0/XX-Naganuma $\times$ Yotei & 7 & 6 & & & & & 1 & & & 6 & & 1 \\
\hline 27 & Sounkyo & X0/XX-Naganuma $\times$ Yotei & 8 & 5 & & & & & 3 & & & & & \\
\hline 29 & Iwamizawa & $\mathrm{X} 0 / \mathrm{XX}$-Naganuma $\times$ Yotei & 17 & 16 & & & $1 ?$ & & & & & & & \\
\hline 30 & Ochiai & $\mathrm{X} 0 / \mathrm{XX}$-Naganuma $\times$ Yotei & 14 & 10 & & & & & & & 4 & & & \\
\hline 32 & Shirakaba & X0/XX-Naganuma $\times$ Yotei & 3 & 2 & & & & & 1 & & & & & \\
\hline 36 & Inasato & X0/XX-Naganuma $\times$ Yotei & 16 & 12 & 4 & & & & & & & 14 & 2 & \\
\hline 37 & Biratori & X0/XX-Naganuma $\times$ Yotei & 2 & 0 & & & & & 2 & & & & & \\
\hline 44 & Akan-A & $\mathrm{XY} / \mathrm{XX}-\mathrm{Standard}$ & 22 & 21 & & & & & 1 & & & 15 & 7 & \\
\hline 45 & Ashoro-B & $\mathrm{XY} / \mathrm{XX}-$ Standard & 11 & & & & & & & & & 8 & 3 & \\
\hline 48 & Senpuku-A & $\mathrm{XY} / \mathrm{XX}-$ Standard & 18 & 17 & & & & & 1 & & & 13 & 5 & \\
\hline 49 & Senpuku-B & $\mathrm{XY} / \mathrm{XX}-$ Standard & 17 & & & & & & & & & 16 & 6 & \\
\hline 50 & Senpuku-C & $\mathrm{XY} / \mathrm{XX}-$ Standard & 14 & & & & & & & & & 11 & 3 & \\
\hline 51 & Senpuku-D & $\mathrm{XY} / \mathrm{XX}-\mathrm{Standard}$ & 7 & & & & & & & & & 6 & 1 & \\
\hline 52 & Teshikaga-A & $\mathrm{XY} / \mathrm{XX}-\mathrm{Standard}$ & 34 & 15 & $1,11 \mathrm{e}$ & $2 \mathrm{e}$ & 1 & & 1 & $2,1 \mathrm{e}$ & & 28 & $1,5 \mathrm{e}$ & \\
\hline 53 & Teshikaga-B & $\mathrm{XY} / \mathrm{XX}-$ Standard & 11 & 10 & & & & & 1 & & & 8 & 3 & \\
\hline 58 & Kiyosato & XY/XX-Standard & 10 & 9 & 1 & & & & & & & 7 & 3 & \\
\hline 60 & Kamirubetsu & $\mathrm{XY} / \mathrm{XX}$-Tanno/Oketo & 19 & 18 & & & & & & & 1 & & & \\
\hline 61 & Kami-koonomai & $\mathrm{XY} / \mathrm{XX} /$ Tanno-Oketo & $9 \mathrm{~b}$ & 7 & 1 & & & & & & 1 & & & \\
\hline 62 & Hakuryu & XY/XX-Tanno/Oketo & 24 & 21 & & & & & 1 & & 2 & & & \\
\hline 63 & Kimpachi-toge & $\mathrm{XY} / \mathrm{XX}$-Tanno/Oketo & $3 b$ & 2 & & & & & & & 1 & & & \\
\hline 65 & Kitami & $\mathrm{XY} / \mathrm{XX}$-Tanno/Oketo & 15 & 12 & 1 & 1 & & & 1 & & & & & \\
\hline 67 & Tanno & $\mathrm{XY} / \mathrm{XX}$-Tanno/Oketo & 19 & 15 & & & & & $8 \mathrm{e}$ & & & & & \\
\hline 68 & Maruseppu & $\mathrm{XY} / \mathrm{XX}$-Tanno/Oketo & 42 & 38 & 4 & & & & & & & 40 & 2 & \\
\hline 69 & Oketo & $\mathrm{XY} / \mathrm{XX}$-Tanno/Oketo & 19 & & & & & & & & & 18 & $1 \mathrm{e}$ & \\
\hline
\end{tabular}

are classified as "Naganuma $\times$ Yotei hybrids" (Figs 1 and 3 ). The frequencies of chromosomes with two arms vary considerably between different localities within this geographical zone. There are some interesting features in the geographical distribution of chromosomal types within this admixed area. In general, these populations are homozygous or heterozygous for the submetacentric $\mathrm{M}_{6}$ chromosome (Fig. 5E-G). Additionally, the acrocentric/ subacrocentric (with heterochromatic arm) form of the $\mathrm{X}$ chromosome generally has an eastern-northerly distribution; it is acrocentric on Iwamizawa (no. 29), Tsukigata (no. 24) and Kamikawa-1 (no. 26) or heterozygous (acrocentric/subacrocentrc) on Sounkyu (no. 27) and Yuubari (no. 25). The subacrocentric with an euchromatic short arm form of the $\mathrm{X}$ chromosome is found mainly in the south-western part of the distribution of the "Naganuma - Yotei hybrids" (Fig. 5F-H) and includes eight localities. Some of them lie across the Hidaka Range (Fig. 1, Table 1, nos 28, 30, 31, 32, 33, 34, and
35). There appears to be a cline of integradation of frequencies within the subrace in the area between localities where the alternative $\mathrm{X}$ chromosome morphs belonging to the "Yotei" subrace are known to be fixed. Grasshoppers in hybrid areas are distributed on the western and eastern slopes of the Hidaka Range.

\section{The neo-XY race}

Samples from 31 localities from the eastern part of Hokkaido and Kunashiri have the neo-XY in the male (2n $=22)$ and neo-XX in the female $(2 n=22)$ type of sex determination. The range of this race could be divided into two chromosome subraces: (1) "XY/XX-Standard" (including the Golovnin population) and (2) "XY/XXTanno/Oketo" subraces (Fig. 1, Table 1, nos 40-70).

The Kunashiri (Golovnin volcano) population was first described as P. kurilensis (Bey-Bienko, 1949). Subsequently, Storozhenko (1993) changed the taxonomic status to $P$. sapporensis kurilensis. Specimens with the karyotype of the Kunashiri population also occur at 
Table 3. Polymorphism of additional chromosome segments in Podisma sapporensis. Locality number (No.) refers to Table 1 and Fig. 1. BB homozygous for the chromosome without extra heterochromatin; BS - heterozygous; SS - homozygous for the chromosome with extra heterochromatin; interstitial C-bands located near the centromere (c) or near the distal (d) part of the chromosome.

\begin{tabular}{|c|c|c|c|c|c|c|c|c|c|c|c|c|c|c|c|c|c|c|c|c|c|c|c|c|c|c|}
\hline \multirow[t]{2}{*}{ No. } & \multirow[t]{2}{*}{ Locality name } & \multirow[t]{2}{*}{ Chromosome type } & \multirow[t]{2}{*}{ Tota } & \multicolumn{3}{|c|}{$\mathrm{L}_{1}$ interst } & \multicolumn{3}{|c|}{$\begin{array}{l}\mathrm{M}_{6} / \mathrm{M}_{5} \\
\text { interst }\end{array}$} & \multicolumn{3}{|c|}{$\begin{array}{c}\mathrm{M}_{6} \text { neo/ } \\
\text { inter }\end{array}$} & \multicolumn{3}{|c|}{$\begin{array}{c}\mathrm{M}_{6} \mathrm{neo} / \\
\text { dist }\end{array}$} & \multicolumn{3}{|c|}{$\begin{array}{c}\mathrm{M}_{7} \text { neo/ } \\
\text { dist }\end{array}$} & \multicolumn{3}{|c|}{$\begin{array}{l}\mathrm{M}_{7 / 8} / \\
\text { distal }\end{array}$} & \multicolumn{3}{|c|}{$\mathrm{S}_{10 / 9}$} & \multicolumn{2}{|c|}{$\mathrm{S}_{11}$ dist } \\
\hline & & & & $\overline{\mathrm{BB}}$ & $\mathrm{BS}$ & SS & $\mathrm{BB}$ & & SS & $\mathrm{BBI}$ & BS & $\mathrm{SS}$ & $\mathrm{BB}$ & BS & SS & & $\mathrm{BS}$ & $\mathrm{SS}$ & $\mathrm{BB}$ & $\mathrm{BS}$ & $\overline{\mathrm{SS} \mathrm{I}}$ & $\mathrm{BB}$ & $\mathrm{BS}$ & SS E & $\mathrm{BB} B \mathrm{~B}$ & $\mathrm{SSS}$ \\
\hline 4 & Shimokawa-B & $\mathrm{X} 0 / \mathrm{XX}-\mathrm{Standard}$ & 10 & 9 & $1 \mathrm{c}$ & 0 & 9 & 0 & 1 & & & & & & & & & & & & & & & & & \\
\hline 6 & Shimokawa-A & $\mathrm{X} 0 / \mathrm{XX}-\mathrm{Standard}$ & 11 & 8 & $1 \mathrm{c}$ & $1 \mathrm{c}, 1 \mathrm{~d}$ & 10 & 0 & 1 & & & & & & & & & & & & & & & & & \\
\hline 7 & Shimokawa (2005) & X0/XX-Standard & 68 & & & & & & & & & & & & & & & & & & & 43 & 3 & 223 & 325 & 31 \\
\hline 10 & Nishi Okoppe-1 & $\mathrm{X} 0 / \mathrm{XX}$-Standard & 8 & & & & & & & & & & & & & & & & 7 & 1 & 0 & 7 & 1 & 0 & & \\
\hline 13 & Bibai & X0/XX-Standard & 14 & & & & & & & & & & & & & & & & 13 & 1 & 0 & & & & & \\
\hline 15 & Ishiyama & X0/XX-Standard & 28 & & & & & & & & & & & & & & & & 26 & 2 & 0 & & & & & \\
\hline 22 & Kuriyama & X0/XX-Naganuma & 23 & & & & & & & & & & & & & & & & & & & 22 & 0 & 1 & & \\
\hline 23 & Naganuma & X0/XX-Naganuma & 51 & & & & & & & & & & & & & & & & & & & 49 & 2 & 0 & & \\
\hline 24 & Tsukigata & $\mathrm{X} 0 / \mathrm{XX}$-Naganuma $\times$ Yotei & 11 & & & & & & & & & & & & & & & & 5 & 4 & 2 & & & & 65 & 0 \\
\hline 26 & Kamikawa-1 & $\mathrm{X} 0 / \mathrm{XX}$-Naganuma $\times$ Yotei & 7 & 6 & 0 & $1 d$ & & & & & & & & & & & & & & & & & & & & \\
\hline 28 & Kamishihoro & X0/XX-Naganuma $\times$ Yotei & 8 & & & & 7 & 1 & 0 & & & & & & & & & & & & & & & & & \\
\hline 30 & Ochiai & X0/XX-Naganuma $\times$ Yotei & 14 & & & & 10 & 3 & 1 & & & & & & & & & & & & & 13 & 0 & 1 & & \\
\hline 35 & Urakawa & X0/XX-Naganuma $\times$ Yotei & 24 & & & & & & & & & & & & & & & & 14 & 9 & 1 & & & & & \\
\hline 40 & Nishi Okoppe-2,4 & XY/XX-Standard & 22 & & & & & & & & & & & & & & & & & & & 20 & 2 & 0 & & \\
\hline 41 & Takinoue & $\mathrm{XY} / \mathrm{XX}-\mathrm{Standard}$ & 9 & 4 & 5 & 0 & & & & & & & & & & & & & & & & & & & & \\
\hline 44 & Ashoro-A & $\mathrm{XY} / \mathrm{XX}-$ Standard & 2 & 1 & 0 & 1 & 2 & 0 & 0 & & & & 0 & 1 & 1 & & & & & & & & & & & \\
\hline 45 & Ashoro-B & $\mathrm{XY} / \mathrm{XX}-$ Standard & 11 & 9 & 0 & $2 d$ & 9 & 0 & 2 & & & & 10 & 1 & 0 & & & & & & & & & & & \\
\hline 46 & Akan-A & $\mathrm{XY} / \mathrm{XX}-\mathrm{Standard}$ & 22 & 19 & 0 & $3 d$ & 17 & 0 & 5 & 20 & 2 & 0 & 19 & 3 & 0 & 20 & 2 & 0 & & & & 21 & 1 & 0 & & \\
\hline 48 & Senpuku-A & $\mathrm{XY} / \mathrm{XX}-$ Standard & 18 & 13 & $2 d$ & $3 d$ & & & & & & & & & & & & & & & & & & & & \\
\hline 49 & Senpuku-B & $\mathrm{XY} / \mathrm{XX}-$ Standard & 17 & 11 & $2 d$ & $4 d$ & 16 & 1 & 0 & & & & 14 & 3 & 0 & & & & & & & & & & & \\
\hline 50 & Senpuku-C & $\mathrm{XY} / \mathrm{XX}-$ Standard & 14 & & & & 13 & 1 & & & & & 13 & 1 & 0 & & & & & & & & & & & \\
\hline 51 & Senpuku-D & $\mathrm{XY} / \mathrm{XX}-$ Standard & 7 & 6 & 0 & $1 d$ & 6 & 1 & 0 & & & & & & & & & & & & & & & & & \\
\hline 52 & Teshikaga-A & $\mathrm{XY} / \mathrm{XX}-\mathrm{Standard}$ & 34 & & & & 33 & 0 & 1 & 30 & 3 & 1 & 32 & 0 & 2 & 33 & 1 & 0 & & & & 31 & 0 & 3 & & \\
\hline 53 & Teshikaga-B & $\mathrm{XY} / \mathrm{XX}$-Standard & 11 & 7 & 0 & $4 d$ & & & & & & & & & & & & & & & & & & & & \\
\hline 55 & Teshikaga & $\mathrm{XY} / \mathrm{XX}-$ Standard & 9 & 4 & 5 & 0 & & & & & & & & & & & & & & & & & & & & \\
\hline
\end{tabular}

twenty localities of the "XY/XX-Standard" chromosome subrace possessing 10 pairs of acrocentric chromosomes and two sex chromosomes (metacentric neo- $\mathrm{X}$ and acrocentric neo- $Y$ in the male and double metacentric neo- $X$ in the female (see Fig. 2 in Bugrov, 1995). This subrace is distributed throughout the eastern part of Hokkaido (Table 1, nos 40-59). This subrace on Hokkaido is divided into two separate populations. One is situated near the northeastern border of the distribution of the X0/XX-Standard subrace (Fig. 1, nos 40-42). The second group of populations occur in the southeast part of Hokkaido (Fig. 1, nos 43-58 and Fig. 2).

At eleven localities studied around Oketo and Tanno (Fig. 1, nos 60-70, Fig. 2) P. sapporensis differ slightly from those at localities with standard neo-XY karyotype in possessing a high frequency of heterozygotes and homozygotes for the inversions in some large and medium sized autosomes (Fig. 4). However, a fixed pericentric inversion with short euchromatic arms on $\mathrm{M}_{3}$ and neo- $\mathrm{M}_{5}$ was observed only at the Tanno locality (see Figs 8 and 9 in Bugrov et al., 2001). This chromosome morphotype is denoted as the "XY/XX-Tanno/Oketo" subrace. This subrace is located between two areas of distribution of the XY/XX-Standard subrace. There is no conspicuous geographic barrier between $\mathrm{XY} / \mathrm{XX}$-standard and XY/XX-Tanno/Oketo subrace. The diagrams show the frequency of polymorphism in this subrace (Fig. 4).

Possible contact zone of $\mathrm{X} 0$ and neo-XY races

In 2005, additional material from the northeastern part of Hokkaido was collected in order to find the contact zone between the $\mathrm{X} 0 / \mathrm{XX}$ and neo-XY/XX races. A total of 350 adult male and female grasshoppers were collected from 12 new localities. The natural hybrid zones between these races have not yet been discovered. However, specimens from Nishi-Okoppe-1,3 and Nishi-Okoppe-2,4 included X0-Standard or neo-XY-Standard races (Table 1, nos 10, 11, and 40, Fig. 1). These populations are separated by about $14 \mathrm{~km}$ and thus the width of this transect is not very long. Moreover, 11 individuals from two localities (26 and 70, respectively) in Kamikawa-1 and Kamikawa-2 consisted of X0/XX-Naganuma/Yotei and $\mathrm{XY} / \mathrm{XX}$-standard (Fig. 1, Table 1) races. These are separated by about $24 \mathrm{~km}$.

\section{$B$ chromosomes, translocations between Bs and autosomes, and $\mathrm{C}$-heterochromatin polymorphism}

B chromosomes were found in 120 specimens belonging to both chromosome races from 38 out of 70 localities (Table 2). These Bs were then subdivided into seven categories according to the structure, size and C-banding content (see Fig. 1 in Warchałowska-Śliwa et al., 2001). The localities and the number of specimens for each category are given in Table 2 . The highest frequency was observed for $\mathrm{B}_{1}$ and $\mathrm{B}_{5 \text { iso }}$ variants, and reached $3 \%$ and $2.03 \%$ in $\mathrm{X} 0$ samples and $0.61 \%$ and $1.06 \%$ in $\mathrm{XY}$ individuals, respectively. Only single individuals of other types $\left(\mathrm{B}_{2}, \mathrm{~B}_{4}\right.$ and $\left.\mathrm{B}_{6 \text { iso }}\right)$ were found. The $\mathrm{B}_{4}$ variant was found at the Naganuma and Yuubari localities (X0 race), whereas the $\mathrm{B}_{6 \text { iso }}$ variant was detected only at Teshikaga (XY/XX race). 
Additionally, a potential interchange between the $\mathrm{B}$ chromosome and one autosome from $\mathrm{M}_{3}$ (Fig. 9 in Warchałowska-Śliwa et al., 2001) was observed at 18 of the 70 localities examined. Fifty-nine males and embryos from the two main races were heterozygous, whereas two specimens were homozygous for this translocation (Table 2).

Moreover, polymorphism of additional segments associated with the occurrence of interstitial or distal extra heterochromatin was identified in individuals from different localities, polymorphic for the presence of six additional C-bands (see Figs 14-17 in Warchałowska-Śliwa et al., 2001; Table 3 in the present paper). In most cases, three different types of bivalents exist: $\mathrm{BB}$ - homozygous for the chromosome without supernumerary heterochromatin, BS - heterozygous and SS - homozygous for the chromosome with extra heterochromatin. For chromosome $\mathrm{L}_{1}, 0.44 \%$ of males from the $\mathrm{X} 0$ race and $2.82 \%$ from the neo-XY race were either heterozygous or homozygous for this supernumerary segment. Variation in the C-banding pattern was due to the presence or absence of thin C-bands located near centromeres (c) or near the distal parts of chromosomes (d). The interstitial segment on $\mathrm{M}_{6}(\mathrm{X} 0), \mathrm{M}_{5}(\mathrm{XY}), \mathrm{S}_{10}(\mathrm{X} 0)$ and $\mathrm{S}_{9}(\mathrm{XY})$ and additionally a distal segment on the last pair showed the same structural basis in the two chromosome races. This differ from the polymorphism in the interstitial and distal $\mathrm{C}$-heterochromatin on $\mathrm{M}_{6}$ and distal $\mathrm{C}$-heterochromatin on $\mathrm{M}_{7}$, which occurred only in the neo-XY race. These polymorphic C-bands were observed with low frequency at different localities (Table 3).

\section{DISCUSSION}

Among orthopteroid insects, $P$. sapporensis is characterized by extremely high chromosome variation. The changes in chromosome set (e.g. translocations, inversions, additional chromosome elements) might be easily fixed and accumulated as a result of random genetic drift. The recognition of the distribution and nature of geographical barriers results in a better understanding of the influence of dispersal on population genetic structure and defines factors responsible for the distribution of favourable mutations (Mantel et al., 2003).

The Naganuma subrace (with a fixed inversion on the $\mathrm{M}_{6}$ autosome) has no clear borders of distribution. The Ishikari river, running through the Naganuma area, seems to be a potential barrier separating $\mathrm{X} 0$-Standard and $\mathrm{X} 0$ Naganuma subraces, which may have facilitated karyotype differentation. Moreover, two types of "hybrids" contain mixed karyotypes a possible result of hybridization between neighbouring $\mathrm{X} 0$-Standard and $\mathrm{X} 0$-Yotei subraces. Beginning in the Naganuma and Yotei areas, populations are highly fragmented throughout the south to the centre of Hokkaido. On the basis of the polymorphism in two armed chromosomes, the frequency of heterozygotes, and the geographical distribution of these localities, two separate areas of hybridization are proposed: the "X0-Standard $\times$ Yotei" (Fig. 1, nos 20, 21) and the "X0-Naganuma $\times$ Yotei" (Fig. 1, nos 25-38). The occurrence of chromosome markers characterizing individual subraces and the frequency of heterozygotes may indicate that neighbouring chromosome subraces have hybridized. However, it cannot be excluded, that the extensive karyotypic variation within the $\mathrm{X} 0$ race is a result of the polymorphism observed within the race, which is more or less continuously variable geographically.

Bugrov et al. (2001) found that $P$. sapporensis is represented by two main allopatric chromosome races, namely $\mathrm{X} 0 / \mathrm{XX}$ and neo-XY/XX, however, the geographic borders between these races have not yet been identified. In a previous paper, we put forward the hypothesis that the $\mathrm{X} 0$ and neo-XY chromosome races may be geographically isolated by a mountainous expanse consisting of the Daisetsu Mts and Hidaka Range, occupying the central part of Hokkaido, and by the sea straits between Hokkaido, Sakhalin and Kunashiri islands. The present investigations have shown that the $\mathrm{X} 0$ race is distributed across the Hidaka Range from their western to eastern slopes (Fig. 1). Thus, it appears that the mountainous system does not represent a geographic barrier that promotes allopatric chromosomal speciation. On the contrary, no conspicuous geographic barrier exists in the area between different chromosomal races. This fact strongly suggests that spatial isolation is not necessary for chromosomal speciation.

In spite of the stability of the X-A Robertsonian translocation leading to strong territorial isolation of the $\mathrm{X} 0$ and neo-XY chromosomal races of $P$. sapporensis, polymorphism in pericentric inversions and additional chromosome elements are common in this species. In some populations the pericentric inversion chromosome changes are fixed in one (Sakhalin population) or some pairs of chromosomes (Mt Daisengen population, $\mathrm{Mt}$ Yotei and Naganuma populations), which enables the identification of separate chromosome subraces. Consequently, we conclude that $P$. sapporensis can be divided into six chromosome subraces, each of which has of at least a single fixed chromosome change in their karyotype.

The majority of the fixed changes in the $\mathrm{X} 0$ race were discovered at two isolated localities: (1) the top of $\mathrm{Mt}$ Daisengen (1072 m a.s.l., X0 Daisengen subrace) and (2) around Mt Yotei (about $1800 \mathrm{~m}$ a.s.l., X0 Yotei subrace) (Fig 1). Obviously these populations have been presumably isolated from other populations for a long time. Each chromosome in the karyotype of this subrace differs from analogous chromosomes in the X0 Standard subrace in having pericentric inversions $\left(\mathrm{M}_{5}, \mathrm{X}\right)$ or a $\mathrm{C}$-positive short arm. To our knowledge, $P$. sapporensis occurs only on the summit of Mt Daisengen on the Oshima Peninsula.

Genetic structure is determined not only by current evolutionary processes but also modelled by the history of populations (Avise, 2000). An analysis of the distribution of chromosomal races and subraces of $P$. sapporensis may be used to reconstruct the history of this species in the Okhotsk Sea region. 
In the Miocene, territories that subsequently transformed into the present-day Kuril Islands, Sakhalin and Hokkaido constituted the eastern end of the Asian continent (Lebedev, 1968). This area was influenced by a moist and warm climate and dominated by deciduous forests (Kryshtofovich, 1955). By the beginning of the Quaternary (ca $2.0 \mathrm{mln}$ years BP), the outlines of the shoreline in the Okhotsk Sea region became closer to the present-day situation. From that time, further basin evolution was controlled mostly by global climatic changes. At the Last Glacial Maximum (15-18 thousand years ago), the sea level decreased by $130 \mathrm{~m}$ and the majority of the present-day shelf was drained, while Sakhalin, Hokkaido, Kunashir and presumably Iturup were integrated into an extensive mountain ridge. This period is characterized by a cooling of the atmosphere that caused a growth of the mountain glaciers on Sikhote-Alin', Hokkaido and Honshu (Bezverkhyi et al., 2002).

Due to these processes, the present-day biodiversity of the Podismimi grasshoppers on Hokkaido is much impoverished compared with the continental biodiversity on the other shore of the Japan and Okhotsk seas. Yet the native species may have originated from here, for example our model species - P. sapporensis. The Last Glacial Maximum had a major affect on the biogeocenoses of the Okhotsk region. In this period forest-tundra dominated in the north of the region and forest-steppe landscapes in the south (Kryshtofovich, 1955). Representatives of relatively thermophilic fauna could have survived only in refuges. During the period of mountain glaciation on Hokkaido, the metapopulation of $P$. sapporensis was probably divided into two main refuges on two sides of the central mountain system separated by the ridges Daisetsu and Hidaka. Owing to the small population sizes in these refuges, neutral or selectively significant evolutionary transformations of the genome may have rapidly spread in the populations of this wingless species with a small radius of reproductive activity. $P$. sapporensis evolved into a unique acridid species, in which chromosome rearrangements frequently appeared and were fixed. It is likely that by virtue of stochastic mechanisms, translocations between the sex chromosome and the fifth pair of autosomes became fixed in the eastern part of the range of this species and resulted in the occurrence of the neo-XY chromosome sex determination. It should be noted that a polymorphism involving additional (B) chromosomes probably occurred in the initial metapopulation of $P$. sapporensis before it separated into $\mathrm{X} 0$ and $\mathrm{XY}$ races. Unique $\mathrm{B}$ morphotypes inherent only to a specific race were not detected in either the standard $\mathrm{X} 0$ or $\mathrm{XY}$ race. FISH analysis also has confirmed the unique origin of clusters of repetitive DNA sequences (18S rDNA) in all morphotypes of $\mathrm{B}$ chromosomes and in additional chromosome elements (Bugrov et al., 2003, 2004).

The evolutionary differentiation of the XY chromosome race in Eastern Hokkaido suggests one more step in the long-term isolation of several populations (XYStandard and XY-Tanno subraces). In the western part of the range, the initial Podismini type of chromosome set was maintained, yet differentiation of the X0 chromosome race into subraces was more intensive in this area. One of the probable reasons for this differentiation is the long-term isolation of the present-day Oshima peninsula (southern part of Western Hokkaido) as an island (Yasuda, 1984). In the southern and northern parts of this peninsula, the chromosome subraces (X0-Daisengen and $\mathrm{X} 0$-Yotei, respectively) differ from the X0-Standard subrace in more than 5 fixed arrangements. During the postglacial transgression of the southern islands of the Kuril ridge, Sakhalin island and Hokkaido were isolated (14,000-11,000 years BP). On the basis of geological and geophysical data, the isolation of Hokkaido island from Sakhalin can be dated to around 12,000-11,000 years BP (Bezverkhyi et al., 2002). It is likely that the formation of another chromosome subrace (X0-Sakhalin, inversion in the X-chromosome) may be associated with this period. According to all known palaeogeographic reconstructions, Kunashiri island was the last to become isolated from Hokkaido. Importantly, the Kunashiri population in a cytological sense is identical to the XYstandard chromosome subrace on Hokkaido.

In summary, the present study describes the distribution pattern of the chromosome races and subraces of $P$. sapporensis. The observed variation is most likely due to a Robertsonian translocation between a sex chromosome and an autosome and also the result of chromosome rearrangements. The fixation level of inversions varied depending on geographic region. Hybrids between the $\mathrm{X} 0 / \mathrm{XX}$ and neo-XY/XX race have not been discovered, presumably implying the evolution of a postzygotic reproductive isolation system. The presence of isolating barriers between chromosome races provides an interpretation of the taxonomic structure of $P$. sapporensis that differs in terms of the sex determination system.

ACKNOWLEDGEMENTS. The authors thank T. Hironaga for collecting samples of Podisma sapporensis from Nakatombetsutown and Y. Sugano for collecting samples of this species from Tanno-town in 2000. The study was supported partially by the State Committee for Scientific Research (KBN), Project No. 2P04C 08826 to E. Warchałowska-Śliwa and A.G. Bugrov; by a JSPS Fellowship for Research in Japan, Project No. RC30026002 to A.G. Bugrov; by JSPS Fellowship for Japanese Young Scientists Project No. 08608 to H. Tatsuta; by a grant of the Russian Fund of the Basic Researches (RFBR) No. 02-0449398 for A.G. Bugrov; by the research program conducted under the $21^{\text {st }}$ Century COE Program on "Neo-Science of Natural History" at the Graduate School of Science, Hokkaido University to E. Warchałowska-Śliwa, S. Akimoto, and H. Tatsuta. A.G. Bugrov would like to express thanks to M. Ohara of the Hokkaido University Museum for organization of the cytogenetic laboratory during his stay as visiting professor in 2005 .

\section{REFERENCES}

Akimoto S., Sakurai Y. \& Tatsuta H. 1993: Geographic variation in the shape and allometry of the brachypterous grasshopper, Podisma sapporensis. Jpn. J. Entomol 61: 625-640 [in Japanese, with English abstr.].

Avise J.C. 2000: Phylogeography: The History and Formation of Species. Harvard University Press, Cambridge, MA, 464 $\mathrm{pp}$ 
Barton N.H. \& Hewitt G.M. 1985: Analysis of hybrid zone. Annu. Rev. Ecol. Syst. 16: 113-148.

Bey-Bienko G.YA. 1949: To the fauna of Dermaptera and Orthoptera of Sakhalin and Kuril Islands. Entomol. Obozr. 30: 308-317 [in Russian].

Bezverkhyi V.L., Pletnev S.P. \& Nabiullin A.A. 2002: Outline of geological structure and development of the Kuril Island system and adjacent regions. In: Flora and Fauna of Kuril Islands. Materials of International Kuril Island Project. Vladivistok, Dalnauka, pp. 9-22 [in Russian].

Bugrov A.G. 1995: Interpopulation sex-chromosome polymorphism in the grasshopper Podisma sapporensis Shir. from Sakhalin and Kurile Islands. Folia Biol. (Kraków) 43: 51-53.

Bugrov A.G. \& Sergeev G.M. 1997: A new grasshopper species of the genus Podisma Bertold (Orthoptera, Acrididae) from the Southern Kuril Island and its karyotypic features. Acta Zool. Cracov. 40: 47-52.

Bugrov A.G., Warchalowska-Śliwa E., Tatsuta H., Perepelov E.A. \& Акімото S. 2000: Distribution pattern of the X0/XX and neo-XY/neo-XX chromosomal races of the brachypterous grasshopper Podisma sapporensis Shir. (Orthoptera, Acrididae) in Hokkaido, Nothern Japan. Entomol. Sci. 3: 693-699.

Bugrov A.G., Warchalowska-Śliwa E., Tatsuta H. \& Akiмото S. 2001: Chromosome polymorphism and C-banding variation of the brachypterous grasshopper Podisma sapporensis Shir. (Orthoptera, Acrididae) in Hokkaido, Nothern Japan. Folia Biol. (Kraków) 49: 137-152.

Bugrov A.G., Karamysheva T.V., Pytakova M.S., Rubtsov D.N., AndReENKova O.V., WarchatowsKa-Śliwa E. \& RubTsov N.B. 2003: Chromosomes of the Podisma sapporensis Shir. (Orthoptera, Acrididae) analysed by chromosome microdissection and FISH. Folia Biol. (Kraków) 51: $1-11$.

Bugrov A.G., Warcha£owska-Śliwa E., Sugano Y. \& Akimoto S. 2004: Experimental hybridization between X0 and XY chromosome races in grasshopper Podisma sapporensis Shir. (Orthoptera, Acrididae). I. Cytological analysis of embryos and F1 hybrids. Folia Biol. (Kraków) 52: 39-45.

CoAtes D.J. \& Shaw D.D. 1982: The chromosomal component of reproductive isolation in the grasshopper Caledia captiva. I. Meiotic analysis of chiasma distribution in two chromosomal taxa and their $\mathrm{F}_{1}$. Chromosoma 86: 509-531.

Gosalvez J., Mason P.L. \& Lopez-Fernandez C. 1997: Differentiation of individuals, populations and species of Orthoptera: the past, present and future of chromosome markers. In Gangwere S.K., Muralirangan M.C. \& Muralirangan M. (eds): The Bionomics of Grasshoppers, Katydids and their Kin. CAB International, London, pp. 355-383.

HewitT G.M. 1979: Grasshoppers and Crickets. Animal Cytogenetics. Vol. 3, Insecta I. Gebrüder Borntraeger, Berlin, 170 pp.

HewitT G.M. \& John B. 1972: Inter-population sex polymorphism in the grasshoppers Podisma pedestris. II. Population parameters. Chromosoma 37: 23-42.

JoHN B. 1983: The role of chromosome change in the evolution of orthopteroid insects. In Sharma A.K. \& Sharma A. (eds): Chromosomes in Evolution of Eukaryotic Groups. Vol. 1. CRC Press, Boca Ration, FL, 110 pp.

John B. \& HewitT G.M. 1970: Interpopulation sex chromosome polymorphism in the grasshopper Podisma pedestris. I. Fundamental facts. Chromosoma 37: 291-308.
KRYShtoforovich A.N. 1955: Development of botanicgeographical areas in north hemisphere since the beginning of tertiary period. Quest. Geol. Asia (Moscow) 2: 824-844 [in Russian].

LeBedev V.G. 1968: General Problems of the Geomorphology of Eastern China. Saratov, 183 pp. [in Russian].

Mantel S., Schwarz M.K., Luikart G. \& Taberlet P. 2003: Landscape genetics: combining landscape ecology and population genetics. Trends Ecol. Evol. 18: 189-197.

Mistschenko L.L. 1952: Fauna USSR. Grasshoppers Catantopinae. Nauka, Moscow-Leningrad, 610 pp. [in Russian].

Moran C. \& Shaw D.D. 1977: Population cytogenetics of the genus Caledia (Orthoptera: Acridinae). III. Chromosomal polymorphism, racial parapatry and introgression. Chromosoma 63: 181-204.

Shaw D.D. \& Wilkinson P. 1980: Chromosome differentation, hybrid breakdown and the maintenance of a narrow hybrid zone in Caledia captiva. Chromosoma 80: 1-31.

Shaw D.D., Webb G.C. \& Wilkinson P. 1976: Population cytogenetics of the genus Caledia (Orthoptera: Acridinae). II. Variation in the pattern of C-banding. Chromosoma 56: 169-190.

ShIRAKI T. 1910: Acrididen Japans. Keiseisya, Yokohama, 90 pp.

Storozhenko S. 1993: To the knowlege of the tribe Melanoplini (Orthoptera, Acrididae: Catantopinae) of the Eastern Palearctic. Articulata 8: 1-22.

Tатsuta H. \& Акімото S. 1994: Analysis of morphological variation in the brachypterous grasshopper, Podisma sapporensis (Orthoptera, Podisminae). Jpn. J. Entomol 62: 225-234 [in Japanese with English abstr.].

Tatsuta H. \& Aкimoto S. 1998: Sexual differences in the pattern of spatial variation in the brachypterous grasshopper, Podisma sapporensis (Orthoptera, Podisminae). Can. J. Zool 76: $1450-1455$.

Tatsuta H., Ito G., Bugrov A.G., Tchernykh A.A. \& Акimoto S. 2000: Multivariate morphometrics of two Podisma species (Orthoptera: Acrididae) in Kunashiri Island. Appl. Entomol. Zool 35: 1-8.

TCHerNyKh A. \& Bugrov A.G. 1997: Karyotype evolution and taxonomic status of the Kuril and Sakhalin islands' populations of Podisma sapporensis Shir. Metaleptea 17: 14.

Warchąowska-Śliwa E., Bugrov A.G., Tatsuta H. \& Akiмото S. 2001: B chromosomes, translocation between B and autosomes, and C-heterochromatin polymorphism of the grasshopper Podisma sapporensis Shir. (Orthoptera, Acrididae) in Hokkaido, northern Japan. Folia Biol. (Kraków) 49: 64-75.

White M.J.D. 1973: Animal Cytology and Evolution. 3rd ed. Cambridge University Press, Cambridge, viii $+961 \mathrm{pp}$.

White M.J.D. 1974: Speciation in the Australian morabine grasshoppers. The cytogenetic evidence. In White M.J.D. (ed.): Genetic Mechanisms of Speciation in Insects. Australia and New Zealand Book Co., Sydney, pp. 57-68.

YASUDA Y. 1984: Oscillations of climatic and oceanographic conditions since last glacial age in Japan. The evolution of the East Asian environment 1: 397-413.

YASUDA Y. 1984: Oscillations of climattic and oceanographic conditions since the last glacial age in Japan. In Whyte R.O. (ed.): The Evolution of the East Asian Environment. Vol. 1. Center of Asian Studies, University of Hong Kong, Hong Kong, pp. 397-413.

Received August 22, 2007; revised and accepted October 23, 2007 